\title{
INTERVIUL PSIHOLOGILOR PRACTICIENI SUB SUPERVIZARE PENTRU TRECEREA LA STADIUL DE PSIHOLOG PRACTICIANT AUTONOM
}

\begin{abstract}
Perioada de supervizare are ca obiectiv consolidarea cunoştințelor teoretice şi a deprinderilor practice din domeniul psihologiei muncii, industriale şi organizaționale. Psihologii care parcurg acest stagiu pe o perioadă de un an sunt în final supuşi unui interviu după care, ca psiholog practician autonom, poate să-şi exercite competențele în domeniul pentru care a optat.

Setul de subiecte pe care este organizat interviul, conține o problematică generală pe care orice psiholog practician trebuie să o cunoască. Ea este extrasă din standardele de competență elaborate de Colegiul Psihologilor, Comisia de Psihologia Muncii, Transporturilor şi Serviciilor (Psihologia Resurselor Umane. 4(1), 2007, p.102-111). În cele ce urmează oferim psihologilor practicieni în supervizare, dar şi supervizorilor, subiectele asupra cărora se concentrează interviul la care vor fi supuşi. Totodată, aceste întrebări, plus standardele de competență la care am făcut referire, trebuie să stea şi în atenția supervizorilor responsabilizândui pentru activitatea la care s-au angajat.
\end{abstract}

\section{TEMATICA EXAMENULUI DE CUNOŞTINȚE PENTRU PROMOVAREA LA O TREAPTA DE COMPETENȚĂ SUPERIOARĂ A PSIHOLOGILOR DIN DOMENIUL PSIHOLOGIEI MUNCII ŞI SERVICIILOR}

\author{
ANALIZA MUNCII \\ 1. Analiza psihologică a muncii - domenii de aplicare. \\ 2. Clasificarea ocupațiilor din România; profile ocupaționale. \\ 3. Planificarea unui program de analiză a muncii - principalele etape şi metode. \\ 4. Analiza muncii centrată pe postul de muncă (metode şi utilizări). \\ 5. Analiza muncii centrată pe deținătorul postului de muncă (metode şi utilizări). \\ 6. Analiza muncii - elaborarea fişei postului (structura).
}

1 Recrutarea Şı SELECȚIA PERSONALULUI

7. Recrutarea personalului - surse interne şi externe de recrutare. Metode şi tehnici de recrutare.

8. Selectia personalului - principii etice.

9. Etapele unui proces de selecție a personalului.

10. Evaluarea în selecția personalului - procedee bazate pe informația biografică (valoare şi limite).

11. Evaluarea în selecția personalului - testarea aptitudinilor cognitive

12. Evaluarea în selecția personalului - testarea aptitudinilor psihomotorii/noncognitive.

13. Evaluarea în selecția personalului - chestionare de personalitate.

14. Evaluarea în selecția personalului - interviul (valoare şi limite).

15. Principalele calități psihometrice ale metodelor de evaluare (validitatea, fidelitatea, standardizarea).

16. Strategii de validare a testelor psihologice (concurentă, predictivă, de conținut, de construct, de aspect).

17. Modalități de determinare a fidelității testelor.

18. Etapele unei proceduri de validare a testelor de selecție a personalului.

19. Etalonarea/standardizarea testelor. Reprezentarea performanțelor la teste sub forma unui profil psihologic.

20. Utilizarea testelor în evaluarea psihologică - exigențe privind alegerea, administrarea, interpretarea şi raportarea rezultatelor (cerințe deontologice).

21. Construcția unui tabel de expectație.

22. Calculul utilității unei proceduri de selecție psihologică.

\section{EVALUAREA PERFORMANȚELOR PROFESIONALE}

23. Evaluarea performanțelor - obiective, motivație, deficiențe în practicile cotidiene. 
24. Etape în proiectarea unei proceduri de evaluare a personalului.

25. Surse de eroare în evaluarea performanțelor profesionale şi tehnici de corectare.

26. Metode de evaluare a performanțelor profesionale - scale de evaluare.

27. Metode de evaluare a performanțelor profesionale - metode de comparare a persoanelor.

28. Metode de evaluare a performanțelor profesionale - scale cu descrieri comportamentale.

29. Calculul utilității unei proceduri de evaluare a performanțelor profesionale.

\section{OBoseala, STRESUL ŞI ACCIDENTELE DE MUNCĂ}

30. Oboseala în muncă - cauze, prevenire şi combatere.

31. Accidentele de muncă - cauze, prevenire şi combatere a accidentelor.

32. Stresul ocupațional - modele şi factori determinanți.

33. Diagnoza stresului ocupațional.

34. Prevenție şi intervenție în managementul stresului ocupațional.

\section{FORMAREA ŞI DEZVOLTAREA PROFESIONALĂ}

35. Noțiuni privind formarea continuă şi dezvoltarea personalului.

36. Proiectarea unui curs de formare profesională.

37. Metode de instruire profesională.

38. Cariera profesională. Proiectarea unui plan de carieră.

39. Instrumente pentru informare şi consiliere privind cariera - clasificarea ocupațiilor, utilizarea profilelor ocupaționale şi a chestionarelor de interese profesionale.

40. Instrumente psihologice de evaluare pentru orientarea carierei - baterii de teste pentru evaluarea aptitudinilor şi chestionare de interese.

\section{PSIHOLOGIA APLICATĂ ÎN SERVICII}

41. Cultură organizațională - modele ale culturii organizaționale şi diagnoza lor. Proceduri de schimbare.

42. Climatul organizațional - modele şi diagnoză. Proceduri de schimbare.

43. Diagnoza organizațională - modele.

44. Planificarea unui studiu de diagnoză organizațională.

45. Instrumente de diagnoză organizațională.

46. Redactarea şi prezentarea unui raport de diagnoză.

47. Planificarea forței de muncă într-o organizație - studiul fluctuației personalului.

48. Modele de schimbare organizațională.

49. Planificarea schimbării organizaționale.

50. Managementul schimbării organizaționale.

51. Satisfacția cu munca prestată - diagnoză şi metode de intervenție şi comunicare a rezultatelor.

\section{Probleme juridice ale exercitării profesiei de Psiholog cu drept de liberă practică}

52. Sectoarele de activitate în care este necesară obținerea atestatelor de liberă practică eliberate de către Colegiul Psihologilor din România, pentru desfăşurarea activităților psihologice

53. Calitatea de furnizor ai serviciilor psihologice în România. Societățile comerciale autorizate in domeniul selecției resurselor umane şi activităților de sănătate umană.

54. Calitatea de beneficiar al serviciilor psihologice în România.

55. Psihologul cu drept de liberă practică salariat. Funcționarea structurilor de psihologie.

56. Condițiile realizării activității de supervizare profesională a psihologilor cu drept de liberă practică.

57. Obținerea certificatului de agreere pentru evaluarea psihologică a personalului cu funcții care concură la siguranța circulației rutiere. Condiții şi proceduri de obținere.

58. Examinarea psihologică şi controlul psihologic periodic a personalului potrivit dispozițiilor Legii nr. 319/2006 privind securitatea şi sănătatea în muncă.

59. Drepturile şi obligațiile psihologilor cu drept de liberă practică. Interdicții şi incompatibilități în exercitarea profesiei de psiholog cu drept de liberă practică. 